\title{
Pengaruh Konteks pada Ilustrasi Buku Pendidikan Karakter terhadap Perilaku Disiplin Anak Usia Dini
}

\author{
Lalita Gilang, Riama Maslan Sihombing, Nedina Sari \\ lalitagilang@yahoo.co.id, riamamaslansihombing@gmail.com,nedinasari@gmail.com \\ Magister Desain Institut Teknologi Bandung
}

\section{The Influence of Context on Book Illustration of Character Education for Early Childhood Discipline Behavior}

\begin{abstract}
This research aims to describe and explain: (1) the difference of influence in disciplinal behavior of the early ages in learning using character education books containing congeniality between context and illustration in the form of story, activity, and activitycomparative; (2) the strongest influence between story, activity, and activity-comparative books containing congeniality between context and illustration to disciplinal behavior of the early age. This research was conducted in TK Kristen Kalam Kudus Surakarta. This research was done with experimental quantitative method. Before the experiment was carried out, early analysis of character education books containing congeniality between context in illustration was done, continued by determining books that fit the criteria in congeniality between context and illustration based on the early analysis and experts' opinions. The experts including book authors who are proficient in the psychological development of the early age, and teachers of kindergartens. Data retrieval was done using instruments. Instruments and data have been validated theoretically and contextually. The results conclude that there is a significant influence of congeniality between context and illustration to disciplinal behavior of the early age in kindergartens. The strongest influence among the books containing congeniality between context in illustration is activity-comparative books.
\end{abstract}

Keywords: Context, illustration, children's book, discipline

\section{Article Info}

Received date: 30 September 2017

Revised date: 8 Oktober 2017

Accepted date: 16 November 2017

\section{PENDAHULUAN}

Pelanggaran disiplin merupakan penghambat kemajuan dalam berbagai aspek kehidupan. Pelanggaran disiplin menjadi bagian penting dari dunia pendidikan. Dalam dunia pendidikan disiplin pada anak usia dini melingkupi ranah kognitif, afektif, dan psikomotorik. Ini mengacu pada teori taksonomi Bloom yang menjelaskan bahwa ranah kognitif menekankan aspek intelektual, seperti pengetahuan, pemahaman, dan mengingat. Ranah afektif terkait dengan emosi, misalnya perasaan, minat, motivasi, dan sikap. Sedangkan ranah psikomotorik menekankan perilaku yang menekankan

keterampilan dalam bentuk gerakan yang dapat diamati (Anderson, 2014). Dengan demikian dalam kajian terhadap Buku Pendidikan Karakter ini menekankan pada perilaku disiplin. Terkait dengan upaya menumbuhkan perilaku disiplin ini, berbagai faktor dapat berpengaruh. Perilaku disiplin pada anak usia dini dapat dipengaruhi oleh berbagai faktor yang meliputi: pengaruh pendidikan di dalam keluarga, sifat dasar yang ada pada anak, dan pengaruh lingkungan belajar anak (Jennifer, 2014: 224-245). Adapun pneliti lain mengemukakan bahwa perilaku disiplin pada anak usia dini dipengaruhi oleh faktor bawaan sebesar $11 \%$, faktor pola asuh di dalam keluarga sebesar $24 \%$, faktor lingkungan bermain sebesar 26\%, dan faktor pendidikan formal sebesar 39\% (Howes, 2015: 27-50). Dari hasil kajian tersebut dapat diketahui bahwa besarnya pengaruh pembelajaran perilaku disiplin didominasi oleh faktor pendidikan formal. 
Karena pendidikan formal merupakan faktor yang memberi pengaruh dominan pada pembentukan perilaku disiplin pada anak usia dini, maka di sinilah perlunya media untuk menyampaikan pembelajaran disiplin ini. Dalam pendidikan untuk memperkuat perilaku disiplin pada anak usia dini, terdapat tiga jenis media, yaitu media visual, media audio, dan media audio-visual. Media visual dijelaskan dalam penelitian Resnick (2013) bahwa media yang hanya dapat digunakan dengan indera penglihatan, bentuknya adalah gambar-gambar yang dipajang di dinding, buku cerita, buku cerita bergambar. Jenis media visual dalam bentuk Buku Pendidikan Karakter ini merupakan media paling sering digunakan oleh guru pada lembaga pendidikan anak usia dini. Ini karena Buku Pendidikan Karakter bermanfaat untuk membantu menyampaikan isi tema pendidikan perilaku disiplin.

Buku sebagai media belajar disiplin bagi anak usia dini merupakan media yang efisien dan efektif. Ini disebabkan buku mudah dibawa dan lebih murah atau lebih terjangkau dari segi finansial. Buku dapat mengembangkan kemampuan anak usia dini dalam berimajinasi dan berperilaku, serta berpikir (Bosert, 2013). Namun demikian, sesuai dengan pernyataan penulis buku anak serta pendapat ahli, buku yang menarik bagi anak usia dini adalah buku yang memiliki kesesuaian konteks dan ilustrasi (Walker, 2012). Buku anak-anak yang menyajikan kesesuaian konteks dan ilustrasi yang memadai dapat mengoptimalkan kesenangan anak menggunakan buku itu. Adapun di antara buku-Buku Pendidikan Karakter untuk anak usia dini, ditemukan Buku Pendidikan Karakter dengan bentuk buku cerita, buku aktivitas, dan buku aktivitas-komparasi. Dengan demikian tujuan penelitian ini adalah mendeskripsikan dan menjelaskan perbedaan signifikansi pengaruh pada perilaku disiplin anak usia dini yang mengikuti pembelajaran menggunakan Buku Pendidikan Karakter dalam bentuk: buku cerita, buku aktivitas, dan buku aktivitas komparasi.

\section{KAJIAN PUSTAKA \\ Konteks pada Ilustrasi Buku Pendidikan Karakter}

Konteks pada buku pendidikan karakter yang khusus ditujukan untuk anak usia dini adalah kesesuaian gambar ilustrasi dengan peristiwa atau kejadian yang disajikan dalam bentuk gambar pada buku untuk anak (Walker, 2015). Konteks dalam buku anak-anak merupakan gambar penjelas informasi dengan peristiwa atau kejadian yang disajikan dalam buku untuk anak (Tuckman, 1987). Adapun Segun (2013) mengemukakan bahwa konteks adalah sajian gambar dan penjelasan singkat yang sangat erat berhubungan dengan kehidupan sehari-hari anak-anak. Konteks yang disajikan di dalam buku anak-anak memperkuat narasi atau cerita. Konteks juga sering diwujudkan dalam bentuk narasi sebagai pendukung gambar ilustrasi.

Dari tema cerita dalam buku pendidikan karakter untuk anak-anak, konteks yang tepat dapat memberi kesenangan kepada pembacanya. Peran konteks yang diwujudkan sebagai sebuah narasi di sebuah buku anak-anak, memberikan pengertian baru dalam hal jeda dan alur. Gaya penyajian konteks yang tepat di sebuah narasi tergantung dari genre sebuah tulisan. Hal yang harus diperhatikan dalam membuat konteks yang sesuai dengan pembacanya dalam sebuah narasi adalah menemukan keseimbangan antara teks dan gambar. Detail bagian dari naskah akan lebih memberi kesan misterius untuk menghasilkan narasi yang menarik. Dialog antara teks dan gambar adalah kunci utama untuk menghasilkan atau menjaga jeda dan alur sebuah narasi dalam sebuah penyajian konteks. Atas pertimbangan inilah kesesuaian konteks dan ilustrasi dalam buku anak menjadi penting.

Indikator kesesuaian konteks pada ilustrasi buku anak telah ditemukan oleh para peneliti terdahulu. Waites \& Daniel (2014: 291-298) melaporkan dalam International Journal of Arts and Education" bahwa kesesuaian konteks meliputi: (a) menggambarkan adegan penting yang terdapat dalam cerita; (b) mewakili seluruh isi cerita dalam bentuk yang utuh 
dan padat; (c) strategi penyampaian pesan melalui gambar dalam buku berulang-ulang untuk memudahkan daya ingat anak; (d) cerita disampaikan dipertegas dengan gambar.

\section{Perilaku Disiplin Anak Usia Dini}

Perilaku disiplin merupakan salah satu dari perilaku yang dikembangkan dalam pendidikan anak usia dini. Adapun pengertian perilaku disiplin diterangkan Walker (2015) berasal dari kata Latin disiplina yang berkaitan dengan dua istilah lain, yaitu discere (belajar) dan discipulus (murid), sehingga perilaku disiplin dapat diartikan apa-apa yang disampaikan oleh seorang guru kepada murid. Penataan perilaku yang dimaksud yaitu kesetiaan dan kepatuhan seseorang terhadap penataan perilaku yang umumnya dibuat dalam bentuk tata tertib atau peraturan harian. Disiplin yaitu latihan batin dan watak dengan maksud supaya segala perbuatannya selalu menaati tata tertib; ketaatan pada aturan dan tata tertib. Hal yang sama juga disampaikan oleh Mufidah (2013: 20-26) bahwa disiplin adalah tata tertib, yaitu ketaatan (kepatuhan) pada peraturan, tata tertib, dan sebagainya. Berdisiplin berarti menaati (mematuhi) tata tertib.

Perilaku disiplin dalam pendidikan bagi anak usia dini dalam kajian ini mengacu pada teori yang dikemukakan Hurlock (1999); Lapointe \& Markham (2014); dan Cloud (2012). Penjelasan tentang definisi dan konsep perilaku disiplin ini diuraikan bahwa pendidikan karakter yang terfokus pada perilaku disiplin merupakan bentuk pendidikan yang dibutuhkan anak usia dini. Arti disiplin pada anak-anak adalah memberikan pengertian tentang perilaku yang baik dan yang buruk. Pendidikan disiplin perlu ditanamkan pada anak bahwa berbuat kesalahan tentu mengandung sejumlah konsekuensi,untuk itulah fungsi hukuman dalam pendidikan anak (Hurlock, 1999). Selain itu juga dijelaskan bahwa perilaku disiplin memiliki ciri khas yang berbeda pada anak dengan latar belakang sosial yang berbeda. Latar belakang yang berbeda dapat mempengaruhi cara anak-anak belajar perilaku disiplin (Hurlock, 1999).

Dari berbagai teori yang dirujuk, dapat disintesiskan bahwa indikator yang terkait dengan salah satu bentuk perilaku disiplin terfokus pada tertib menunggu giliran, terdiri atas: (a) menunggu giliran ketika berbaris masuk kelas; (b) menunggu giliran pada waktu guru membagikan buku pelajaran; (c) menunggu giliran ketika mengembalikan buku kepada guru; (d) menunggu giliran menjawab pertanyaan dan bertanya; (e) menunggu giliran ketika dibagikan alat permainan; dan (f) menunggu giliran ketika mengembalikan alat permainan kepada guru.

\section{METODE PENELITIAN}

Penelitian dilaksanakan pada Bulan Maret sampai Bulan Juli 2017. Penelitian dilaksanakan dengan metode kuantitatif eksperimental yang mengacu pada Christensen (2001). Sebelum dilakukan eksperimen, terlebih dahulu dilakukan analisis isi buku-buku pendidikan karakter yang bertema "Perilaku Disiplin", analisis ini mengacu pada Tuckman (1987). Analisis isi dengan fokus pada buku yang di dalamnya terdapat kesesuaian konteks dan ilustrasi dilanjutkan penetapan buku yang tepat untuk diterapkan dalam pembelajaran. Penentuan ini mengacu pada pendapat expert. Expert, meliputi ahli di bidang psikologi perkembangan anak usia dini, pengarang buku untuk anak, dan guru pada taman kanakkanak.

Pelaksanaan eksperimen bertujuan membandingkan besarnya pengaruh antara Buku Pendidikan Karakter jenis buku cerita, buku aktivitas, dan buku aktivitas-komparasi. Pemberian perlakuan penerapan tiga jenis buku dilakukan sebanyak enam belas kali tatap muka. Setiap tatap muka dilaksanakan selama tiga puluh menit yang terbagi atas sesi pembuka, sesi pembagian buku, sesi menyimak buku, sesi menggunakan buku, dan sesi interaksi dengan guru dengan menggunakan buku. 
Pengaruh Konteks pada Ilustrasi Buku Pendidikan Karakter terhadap Perilaku Disiplin Anak Usia Dini (Lalita Gilang, Riama Maslan Sihombing, Nedina Sari)

Eksperimen dilaksanakan di Kota Surakarta Jawa Tengah, pada tiga rumpun sampel murid taman kanak-kanak kelas B di TK Kristen Kalam Kudus. Jumlah seluruh sampel adalah 60 murid. Pengambilan data dilakukan menggunakan instrumen, dan cek-list melalui observasi. Instrumen telah divalidasi menggunakan teknik validitas isi dan validitas interratter. Adapun analisis data setelah eksperimen menggunakan statistik One-Way Anova melalui vasilitas SPSS versi-17.

\section{HASIL PENELITIAN DAN PEMBAHASAN}

Hasil analisis isi pada kegiatan pra-eksperimen penelitian menemukan masing-masing satu buku jenis buku cerita, buku aktivitas, dan buku aktivitas komparasi. Ketiga buku ini mempunyai konteks yang disajikan dalam ilustrasi sesuai dengan perkembangan anak usia dini. Kesesuaian konteks dan ilustrasi ketiga buku ini dapat dilihat pada gambar berikut ini.

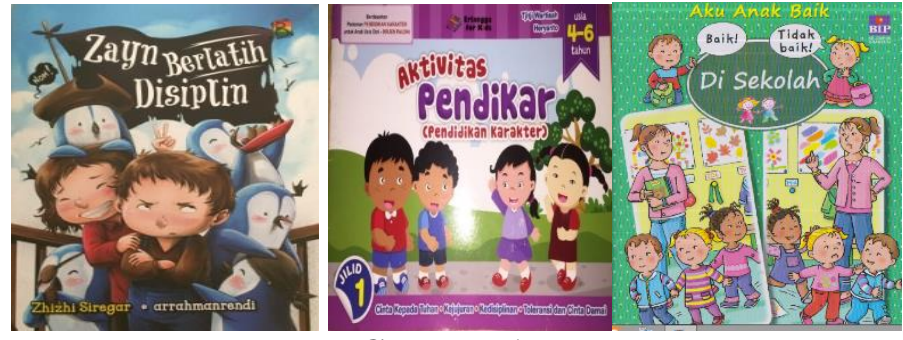

Gambar 1.

Konteks pada Ilustrasi Buku Cerita, Buku Aktivitas, dan Buku Aktivitas-Komparasi

Di dalam buku "Zayn Berlatih Disiplin". Kesesuaian konteks dan ilustrasi tergambar konteks linguistik, konteks emotif, situasional, dan menggambarkan ilustrasi tokoh yang memberi contoh kebaikan, selain itu warna yang disajikan dalam ilustrasi buku ini cerah, sehingga warna-warna dapat membangkitkan rasa gembira. Dengan demikian, buku cerita "Zayn Berlatih Disiplin" ini mempunyai kesesuaian konteks dan ilustrasi yang sesuai untuk mengajarkan perilaku disiplin pada anak usia dini.

Buku Aktivitas Pendikar menyajikan konteks yang sesuai ilustrasi digambarkan dengan penggunaan percakapan yang sesuai dengan ragam bahasa anak, menggambarkan konteks emotif, sesuai dengan kehidupan anak, ilustrasi tokoh menggambarkan contoh kebaikan, dan ilustrasi dengan warna yang menarik. Di dalam Buku "Aku Anak Baik di Sekolah" konteks emotif dalam ilustrasi sesuai untuk membangkitkan rasa gembira anak. Ilustrasi tokoh cerita menggambarkan contoh perilaku baik, sesuai dengan konteks situasional kehidupan anak, dan ilustrasi disajikan dengan gambar berwarna menarik. Dalam buku ini juga disajikan dialog dengan menggunakan bahasa yang sesuai dengan ragam bahasa anakanak.

Hasil penelitian tentang pengaruh perilaku disiplin berikutnya diperoleh penilaian peningkatan skor perilaku disiplin hasil eksperimen. Eksperimen dilaksanakan pada tiga kelompok Sampel. Berdasarkan skor pra-treatment dan skor post-treatment di tiga rumpun sampel secara keseluruhan perbandingan skor pre-treatment v.s post-treatment pada ketiga kelompok yang belajar menggunakan Buku Cerita (BC), Buku Aktivitas (BA), dan Buku Aktivitas Komparasi (BAK), secara keseluruhan skor pos-treatment-nya lebih baik. Adapun rata-rata skor post-treatment kelompok yang menggunakan buku aktivitas komparasi lebih baik dari kedua kelompok lainnya menunjukkan pengaruh kesesuaian konteks dan ilustrasi yang terdapat pada buku aktivitas-komparasi berjudul "Aku Anak Baik" ini memang lebih baik. Namun untuk membuktikan ini, perlu dilakukan pembuktian hipotesis.

Pembuktian hipotesis dalam penelitian ini didahului dengan uji normalitas dan homogenitas. Pengujian normalitas dan homogenitas untuk memenuhi persyaratan penggunaan One-Way-Anova dalam pembuktian hipotesis (Christensen, 2001). Berdasarkan 
uji Kolmogorof Smirnov dan Uji Lavene's-Test secara keseluruhan telah diperoleh pembuktian bahwa data secara keseluruhan berasal dari populasi yang berdistribusi normal, dan homogen.

Setelah memenuhi persyaratan normalitas dan homogenitas, hasil pengujian hipotesis tentang signifikansi perbedaan pengaruh kesesuaian konteks dan ilustrasi pada ketiga buku terhadap perilaku disiplin murid secara keseluruhan di tiga lokasi didapat hasil penghitungan bahwa: $\mathrm{F}$ hitung $=76,679<285,0$. Ini menunjukkan bahwa Ho ditolak, artinya Hipotesis alternatif diterima, artinya hipotesis alternatif yang menyatakan bahwa terdapat perbedaan signifikan pada perilaku disiplin antara murid yang menggunakan buku aktifitas, buku cerita, dan buku aktivitas komparasi yang di dalamnya mengandung kesesuaian konteks dan ilustrasi, adalah benar adanya. Dengan diterimanya hipotesis pertama tersebut, analisis ini dilanjutkan dengan cara mengikuti ketentuan langkah uji One-Way Anova. Langkah selanjutnya dilakukan pengujian Post-Hoc. Adapun ringkasan hasil penghitungan Post-Hoc dilakukan dengan menggunakan software SPSS.

Uji Post-Hoc dapat membedakan rata-rata signifikansi perbedaan mean (rata-rata hitung) tiap kelompok, dan masih dilengkapi dengan homogenous subsets. Kelengkapan ini merupakan bagian dari langkah menuju penentuan signifikansi perbedaan rata-rata pengaruh secara keseluruhan. Adapun penghitungannya terdapat pada Tabel-1 berikut ini.

Tabel 1.

Homogenous Subsets Perbedaan Kekuatan Pengaruh Antara Tiga Kelompok

\begin{tabular}{l|r|r|c|c}
\hline Variabel & \multicolumn{4}{|c}{ Perilaku Disiplin } \\
\hline & & \multicolumn{3}{|c}{ Subset for alpha $=0.05$} \\
Kesesuaian Konteks \& Ilustrasi & N & \multicolumn{1}{|c|}{1} & \multicolumn{1}{c}{2} & \multicolumn{1}{c}{3} \\
\hline Buku Aaktivitas & 20 & $\mathbf{3 . 8 4}$ & & \\
Buku Cerita & 20 & & $\mathbf{8 . 4 9}$ & \\
Buku Aktivitas-Komparasi & 20 & & & $\mathbf{1 3 . 3 7}$ \\
Sig. & & 1.000 & 1.000 & 1.000 \\
\hline
\end{tabular}

Pada Tabel 1 tentang Homogenous Subsets, diperoleh keputusan yang saling melengkapi dalam pengujian hipotesis kedua tentang kekuatan pengaruh kesesuaian konteks dan ilustrasi buku Aktivitas-Komparasi "Aku Anak Baik di Sekolah" sebagai yang paling kuat pengaruhnya secara signifikan. Peningkatan perilaku disiplin murid yang menggunakan Buku Aktivitas-Komparasi lebih baik daripada yang menggunakan Buku Cerita, dan lebih baik daripada yang menggunakan Buku Aktivitas secara signifikan. Dengan demikian dapat diambil kesimpulan bahwa hipotesis alternatif yang menyatakan bahwa di antara buku-buku pendidikan karakter yang memiliki kesesuaian konteks dan ilustrasi, "buku aktivitas komparasi" paling kuat secara signifikan memberi pengaruh daripada "buku cerita" dan "buku aktivitas", terhadap perilaku disiplin anak usia dini, adalah benar adanya.

\section{PEMBAHASAN}

Dari hasil penelitian melalui eksperimen ditemukan bahwa tidak semua data tentang indikator perilaku disiplin dapat diambil, dideskripsikan, dan dianalisis. Oleh karena itu dalam proses eksperimen ini terlebih dahulu diperoleh data melalui deskripsi data yang berasal dari subindikator perilaku disiplin yang dirinci atas: (1) tertib menunggu giliran berbaris masuk kelas; (2) tertib menunggu giliran ketika guru membagikan buku; (3) tertib menunggu giliran mengembalikan buku; (4) tertib menunggu giliran menjawab pertanyaan guru dan bertanya; (5) tertib menunggu giliran ketika dibagikan alat permainan/pelajaran; dan 
(6) tertib menunggu giliran ketika mengembalikan alat permainan/pelajaran. Penentuan sub indikator ini merupakan sintesis dari (Tu’U, 2004 dan Wantah, 2005: 135).

Dalam data penelitian hasil eksperimen ini dipaparkan deskripsi data tentang pengaruh penerapan tiga jenis kategori buku cerita, buku akivitas, dan buku aktivitaskomparasi terhadap indikator perilaku disiplin atas enam subindikator yang telah ditetapkan seperti tersebut di atas. Adapun paparan deskripsi data tersebut merupakan akumulasi dari tiga lokasi penelitian, yaitu kelompok yang belajar menggunakan Buku Cerita "Zayn Belajar Disipli"; kelompok yang belajar menggunakan Buku "Aktivitas Pendikar", dan kelompok yang belajar menggunakan Buku Aktivitas-Komparasi "Aku Anak Baik di Sekolah".

Dari paparan deskripsi data tentang perilaku disiplin pada enam subindikator tersebut semuanya menunjukkan adanya peningkatan skor perilaku disiplin. Peningkatan skor perilaku disiplin dapat dilihat pada batang diagram penunjuk pos-treatment yang lebih besar daripada pre-treatment. Peningkatan skor nilai perilaku disiplin ini ada pada semua subindikator yang dinilai yaitu: (1) tertib menunggu giliran berbaris masuk kelas; (2) tertib menunggu giliran ketika guru membagikan buku; (3) tertib menunggu giliran mengembalikan buku; (4) tertib menunggu giliran menjawab pertanyaan guru dan bertanya; (5) tertib menunggu giliran ketika dibagikan alat permainan/pelajaran; dan (6) tertib menunggu giliran ketika mengembalikan alat permainan/pelajaran.

Peningkatan skor perilaku disiplin tersebut di atas menandakan bahwa pemakaian ketiga kategori jenis buku tersebut sama-sama dapat digunakan sebagai media untuk mengajarkan perilaku disiplin pada bagi anak usia dini. Ini disebabkan ketiga kategori jenis buku yaitu Buku Cerita "Zayn Belajar Disiplin", Buku "Aktivitas Pendikar", dan Buku Aktivitas-Komparasi "Aku Anak Baik di Sekolah", semuanya mempunyai kesesuaian konteks dan ilustrasi yang baik dan penuh. Hasil penelitian terdahulu terkait dengan penelitian ini mengemukakan bahwa hasil post-reatment yang lebih baik dibandingkan dengan hasil pre-treatment dapat diartikan sebagai wujud adanya peningkatan perilaku disiplin (Resnick, 2003: 14).

Itu semua disebabkan oleh kekuatan konteks dan ilustrasi yang sesuai dengan kondisi anak didik. Dikemukakan pula oleh Resnick (2003, 15-18) bahwa dalam untuk memperkuat perilaku disiplin pada anak usia dini, terdapat tiga jenis media, yaitu media visual, media audio, dan media audio-visual. Media visual dijelaskan Resnick (2003) sebagai media yang hanya dapat digunakan dengan indera penglihatan, bentuknya adalah gambar-gambar yang dipajang di dinding, buku cerita, buku cerita bergambar, dan buku yang disajikan dalam bentuk permainan, atau buku yang membuat anak menebak gambar. Jenis media visual ini merupakan media yang paling sering digunakan oleh guru pada lembaga pendidikan anak usia dini. Tujuannya untuk membantu menyampaikan isi tema pendidikan karakter khususnya perilaku disiplin. Dengan demikian, ketiganya dapat dikatakan sebagai buku yang mempunyai kesesuaian konteks pada ilustrasi serta dapat berpengaruh terhadap peningkatan perilaku disiplin pada anak usia dini.

Dalam data penelitian hasil eksperimen ini dipaparkan deskripsi data tentang pengaruh penerapan tiga jenis kategori buku cerita, buku akivitas, dan buku aktivitaskomparasi terhadap indikator perilaku disiplin atas enam subindikator yang telah ditetapkan seperti tersebut di atas. Adapun paparan deskripsi data tersebut merupakan akumulasi dari tiga kelas yang menjadi sampel penelitian, yaitu kelompok yang belajar menggunakan Buku Cerita "Zayn Belajar Disiplin"; kelompok yang belajar menggunakan Buku "Aktivitas Pendikar", dan kelompok yang belajar menggunakan Buku Aktivitas-Komparasi "Aku Anak Baik di Sekolah".

Dari hasil pengujian hipotesis yang bertujuan membuktikan signifikansi perbedaan pengaruh buku pendidikan karakter yang memiliki kesesuaian konteks pada ilustrasi, antara yang berjenis "buku cerita", "buku aktivitas", dan "buku aktivitas komparasi", terhadap 
perilaku disiplin anak usia dini tersebut telah diperoleh dari penghitungan menggunakan software SPSS vesi-17. Dari penghitungan ditemukan bahwa data ketiga kelompok baik yang belajar menggunakan buku cerita, menggunakan buku aktivitas, maupun yang menggunakan buku aktivitas-komparasi, kesemuanya terbukti berasal dari populasi yang berdistribusi normal. Ini menandakan bahwa anak-anak usia dini di seluruh rumpun sampel penelitian ini perilaku disiplinnya dalam keadaan normal berdasarkan penghitungan statistik.

Hasil tersebut di atas dapat dicapai karena penelitian ini menggunakan sampel besar pada setiap kelompok. Ini sesuai dengan penjelasan Christensen (2001) bahwa Uji Normalitas sebagai sebuah uji yang dilakukan dengan tujuan untuk menilai sebaran data pada sebuah kelompok data atau variabel, sebagai sebuah sebaran data yang berdistribusi normal ataukah tidak. Uji Normalitas berguna untuk menentukan data yang telah dikumpulkan berdistribusi normal atau diambil dari populasi normal. Dalam penghitungan statistik, data yang banyaknya lebih dari 30 angka ( $\mathrm{n}>30$ ), maka dapat diasumsikan berdistribusi normal Christensen, 2001). Banyaknya sampel tersebut tergolong sebagai sampel besar.

Adapun hasil pengujian homogenitas dalam penelitian ini menunjukkan bahwa data ketiga kelompok baik yang belajar menggunakan buku cerita, menggunakan buku aktivitas, maupun yang menggunakan buku aktivitas-komparasi, kesemuanya terbukti berasal dari populasi yang homogen. Diperolehnya data berasal dari data yang homogen ini sesuai dengan penjelasan Tukcman (1987). Pengujian hipotesis ini menggunakan teknik Uji One-Way Anova, dan menggunakan fasilitas software SPSS versi-17. Hipotesis yang menyatakan bahwa, "Terdapat perbedaan pengaruh signifikan antara buku pendidikan karakter yang memiliki kesesuaian konteks dan ilustrasi, antara yang berbentuk "buku cerita", "buku aktivitas", dan "buku aktivitas-komparasi", terhadap perilaku disiplin anak usia dini. Setelah penghitungan dilakukan, ternyata hipotesis tersebut memang benar adanya. Dengan demikian, kesesuaian konteks pada ilustrasi yang terdapat pada Buku Pendidikan Karakter benar-benar dapat berpengaruh secara signifikan untuk mengajarkan perilaku displin bagi anak usia dini yang belajar di taman kanak-kanak.

Hasil pembuktian tersebut ternyata berbeda dengan dengan hasil penelitian yang disampaikan oleh Raharjo (2016: 206-216) bahwa pembelajaran untuk anak usia dini memerlukan pengintegrasian high level of play ke dalamnya karena dapat mengembangkan semua aspek perkembangan anak secara optimal. Dalam penelitian pengaruh konteks pada ilustrasi buku anak ini high level of play tidak semata-mata permainan dengan alat, tetapi bermain dengan menyimak buku bergambar dengan tema pendidikan karakter disiplin. Potensi optimal dapat dicapai dengan cara ini karena baik aspek kognitif, afektif, maupun psikomotor dapat diperoleh anak.

Lebih dari itu, buku aktivitas-komparasi yang memiliki kesesuaian konteks dan ilustrasi berjudul "Aku Anak Baik di Sekolah", terbukti lebih efektif dan signifikan untuk mengajarkan perilaku disiplin pada anak usia dini di taman kanak-kanak, dibandingkan dengan dua kategori jenis buku yang juga memiliki kesesuaian konteks dan lustrasi yaitu Buku Cerita "Zayn Belajar Disiplin" dan Buku "Aktivitas Pendikar". Ini seiring sejalan dengan hasil penelitian terdahulu yang menemukan bahwa buku dengan konteks dan ilustrasi pada buku anak berpengaruh terhadap hasil belajar dalam aspek kognisi atau berpikir (Klanten \& Hellige, 2012), sedangkan Jennifer (2014) dalam penelitiannya membuktikan bahwa kurangnya aspek visual mengahsilkan pemahaman yang kurang memadai pada anak didik usia dini. Adapun Walker (2015) menemukan perbedaan pula, yaitu ilustrasi dan konteks yang diperlukan dalam buku untuk anak usia dini. Dari hasil-hasil penelitian yang telah ditemukan terdahulu itu, semuanya seiring sejalan dengan hipotesis yang telah ditemukan dalam penelitian tentang "Pengaruh konteks pada ilustrasi buku pendidikan karakter terhadap perilaku disiplin anak usia dini”. 
Meskipun hipotesis ini telah terbukti, di lokasi penelitian TK Kalam Kudus Surakarta, pada kelompok yang belajar dengan Buku "Aktivitas Pendikar" ada murid yang tidak menunjukkan peningkatan perilaku disiplin yaitu murid dengan nomor 015/KKBA. Murid ini tidak menunjukkan peningkatan perilaku disiplin pada seluruh subindikator. Penjelasan guru terkait murid ini adalah, yang bersangkutan adalah anak berkebutuhan khusus. Murid ini merupakan murid penyandang autis.

Pada kelompok sampel yang berbeda, yaitu kelompok yang belajar menggunakan buku cerita "Zayn Belajar Disiplin", juga terdapat murid yang tidak menunjukkan peningkatan perilaku disiplin setelah program pembelajaran selesai. Ini ada pada murid dengan nomor 010/TABC. Berdasarkan penjelasan guru dapat diketahui bahwa murid yang bersangkutan sering tidak masuk sekolah dengan izin sakit. Murid ini memang tampak tidak sehat secara fisik, sehingga ia juga menunjukkan perilaku ketidakmampuan dalam mengikuti pembelajaran dan disiplin sekolah.

Ketiadaan peningkatan perilaku disiplin yang lain juga terdapat pada kelompok yang belajar dengan buku aktivitas-komparasi "Aku Anak Baik di Sekolah". Terdapat Murid bernomor 004/TPBAK. Hasil wawancara dengan guru diketahui bahwa murid ini lambat tidak hanya dalam belajar disipin, tetapi juga pada bidang-bidang lain. Murid ini sering menunjukkan perilaku semaunya sendiri. Latar belakang keluarga murid sebenarnya baikbaik saja, namun berdasarkan penjelasan guru, orang tua murid tidak memperhatikan perkembangan anaknya. Ini dapat diketahui bahwa orang tua murid tersebut tidak pernah berkomunikasi dengan guru. Bahkan pengambilan laporan hasil studi pada akhir semester pun bukan orang tuanya yang mengambilkan.

Dari hasil pengamatan di tiga kelompok sampel yang belajar menggunakan tiga jenis buku yang berbeda pada waktu pelaksanaan eksperimen, ternyata juga didapatkan muridmurid yang tidak dapat meningkat perilaku disiplin saat belajar dengan menggunakan buku yang mengandung kesesuaian konteks pada ilustrasi. Meskipun hasil pengujian normalitas dan homogenitas diperoleh penghitungan bahwa data berasal dari populasi yang berdistribusi normal dan homogen. Selain itu hasil, penghitungan dalam pembuktian hipotesis juga membuktikan ada pengaruh kesesuaian konteks dan ilustrasi pada buku pendidikan karakter terhadap perilaku disiplin pada anak usia dini.

Hasil observasi dan wawancara dengan guru menemukan adanya penyimpanganpenyimpangan individu menjadi penyebabnya, bukan karena konteks pada ilustrasi buku, melainkan karena variabel lain yang belum dikaji dalam penelitian ini. Berkaitan dengan hal ini, maka dapat diketahui bahwa kesesuaian konteks pada ilustrasi buku pendidikan karakter ini tidak berpengaruh pada murid-murid dengan kondisi khusus. Kondisi khusus yang meliputi: latar belakang murid dengan orang tua yang tidak memperhatikan, anak yang sering sakit, dan anak yang menyandang berkebutuhan khusus atau autis. Variabel-variabel tersebut berbeda dengan hasil riset yang ditemukan Subadi \& Dahroni (26-34) yang menemukan bahwa perubahan kurikulum lah yang menjadi kondisi khusus yang menjadi penghambat bagi anak dalam belajar.

Anak-anak dengan situasi berbeda ini memang membutuhkan tindakan khusus apabila diajarkan perilaku disiplin. Kesesuaian konteks dan ilustrasi tidak efektif untuk meningkatkan perilaku disiplin kepada mereka. Oleh karena itu diperlukan media lain yang perlu dikaji secara ilmiah, oleh para peneliti berikutnya, atau dalam waktu berikutnya setelah penelitian ini selesai. Hal ini dapat mengakomodasi peneliti terdahulu yang menemukan bahwa pendidikan seni dapat menjadi strategi untuk meningkatkan kualitas pembelajaran bagi anakanak berkebutuhan khusus (Mareza, 2017: 35-38).

Pada fenomena anak yang tidak berkebutuhan khusus atau anak di dalam perkembangan yang lebih dewasa, perlakuan untuk pembelajaran disiplin berbeda pula, ini pernah dikaji oleh peneliti terdahulu, Mawarto (2016: 102-116) mengemukakan hasil 
penelitian bahwa kedisiplinan dapat ditingkatkan melalui konseling kelompok. Bedanya hasil penelitian ini dengan penelitian pada anak usia dini adalah, subjek penelitian anak usia dini adalah anak-anak yang belum kooperatif untuk konseling, sehingga pengaruh konteks pada ilustrasi buku dapat menjadi andalan apabila digunakan sebagai media penyampaian pesan perilaku disiplin. Karena itu, terkait dengan kekuatan pengaruh jenis buku aktivitaskomparasi dibanding dengan jenis buku cerita dan buku aktivitas yang semuanya terkandung kesesuaian konteks pada ilustrasinya seperti yang telah ditemukan dalam penelitian ini, menandakan bahwa bilamana anak-anak belajar perilaku disiplin menggunakan buku aktivitas-komparasi terdapat tiga aspek yaitu kognitif, afektif, dan psikomotorik yang terlibat. Pada buku cerita, hanya aspek kognitif dan afektif saja yang dapat terlibat pada anak. Adapun pada buku aktivitas hanya kognitif dan psikomotorik saja yang terlibat, sehingga kesesuaian konteks dan ilustrasi pada buku aktivitas-komparasi dapat berpengaruh lebih kuat secara signifikan.

\section{SIMPULAN DAN SARAN}

Di antara ketiga jenis, Buku Pendidikan Karakter berjudul "Zayn Berlatih Disiplin"; buku "Aktivitas Pendikar"; dan Buku aktivitas-komparasi "Aku Anak Baik di Sekolah", mengadung kesesuaian konteks dan ilustrasi yang lengkap sesuai dengan indikator konteks linguistik, konteks emotif, konteks situasional, ilustrasi memberi contoh perilaku baik, dan terdapat sajian ilustrasi dengan warna cerah.

Berdasarkan hasil eksperimen dan analisis data statistik terbukti hipotesis penelitian bahwa terdapat perbedaan pengaruh yang sinifikan Buku Pendidikan Karakter yang memiliki kesesuaian konteks dan ilustrasi, antara jenis "buku cerita", "buku aktivitas", dan "buku aktivitas-komparasi”, terhadap perilaku disiplin anak usia dini.

Buku yang mengandung kesesuaian konteks dan ilustrasi dengan jenis aktivitaskomparasi mempunyai pengaruh lebih kuat dibanding dengan jenis buku cerita dan buku aktivitas. Ini disebabkan di dalam belajar perilaku disiplin, anak yang menggunakan buku aktivitas-komparasi memperoleh tiga aspek pengalaman belajar yaitu kognitif (daya pikir), afektif (sikap), dan psikomotorik (perilaku). Pada anak yang belajar dengan buku cerita, hanya aspek kognitif dan afektif saja pengalaman belajar yang diperoleh. Adapun pada anak yang belajar dengan buku aktivitas hanya kognitif dan psikomotorik saja pengalaman belajar yang diperoleh. Dengan demikian, kesesuaian konteks dan ilustrasi pada buku aktivitaskomparasi dapat berpengaruh lebih kuat secara signifikan.

Dari simpulan ini diajukan saran terutama bagi para pendidik khususnya pendidik anak usia dini, baik di sekolah formal (taman kanak-kanak/Pendidikan Anak Usia Dini), dimohon memilih buku-buku yang tepat jika mengajarkan perilaku, khususnya perilaku disiplin yang merupakan salah satu aspek dalam mendidik karakter. Buku dengan konteks dan ilustrasi yang sesuai telah terbukti berpengaruh terhadap perilaku disiplin bagi anak usia dini, sehingga para pendidik hendaknya menggunakan buku-buku yang mengandung kesesuaian konteks pada ilustrasi yang tepat.

\section{DAFTAR PUSTAKA}

Anderson, L.W. 2014. Use Bloom's Taxonomy In The Classroom. London: Blackwell Publisher.

Bossert, Jill. 2013. Children's Book Illustration. New York: Roto Vision Publ.

Christensen, Larry B. 2001. Experimental Methodology. Sydney: Alyn and Bacon Inc.

Cloud, David. W. Child Discipline. 2012. Port Hourton : Way of life Literature Publishing. 
Pengaruh Konteks pada Ilustrasi Buku Pendidikan Karakter terhadap Perilaku Disiplin Anak Usia Dini (Lalita Gilang, Riama Maslan Sihombing, Nedina Sari)

Howes,Carolee. 2015. "Children's pre-academic achievement in pre-Kindergarten programs". Early Childhood Research Quarterly, 30 (1), 27-50.

Hurlock, E.B. 1999. Psikologi Perkembangan Anak. Jakarta: Erlangga.

Jennifer, M. 2014. Reading Contemporary Illustrated Children's Book. Children's Literature, 42(1) $24-245$.

Klanten, R. \& Hellige, H. 2012. Little Big Books: Illustrations for Children's Picture Book. New York: Gestalten Publisher Ltd.

Lapointe, V \& Markham, L.2014. Discipline Without Damage: How to Get Your Kids to Behave Without Messing Them. London: Longman Publ.

Mareza, Lia. 2017. Pendidikan Seni Budaya sebagai Strategi Interfensi Umum bagi Anak Berkebutuhan Khusus. Scholaria. Jurnal Pendidikan dan Kebudayaan, 7(1),35-38.

Mawarto, Mawarto. 2016. Efektivitas Konseling Kelompok dengan Memanfaatkan Model untuk Meningkatkan Kedisiplinan Siswa. Scholaria Jurnal Pendidikan dan Kebudayaan, 6 (1),102-116.

Mufidah, H. 2013. Kasus Perilaku Pelanggaran Disiplin Ditinjau dari Kerangka Teori Sosiologi Fungsionalisme. Jurnal Pendidikan Inovatif Universitas Pendidikan Indonesia, 4(2), 20-26.

Raharjo, Maria Melita. 2016. Menciptakan High Level of Play dalam Rencana Pembelajaran Anak Usia Dini. Scholaria Jurnal Pendidikan dan Kebudayaan, 6 (3), 206-216.

Resnick, Elizabeth. 2003. Design for Communication: Conceptual Graphic Design Basics. New Jersey: John Wiley \& Sons Inc.

Segun. M. 2013. "The Importance of Illustrations in Children's Books".in Illustrating for Children's Book. Ibadan: CLAN. pp 25-27.

Subadi, Tjipto \& Dahroni. 2017. Model Pelatihan Guru Ilmu Pengetahuan Sosial di SMP Muhammadiyah Kartasura. Scholaria Jurnal Pendidikan dan Kebudayaan, 7 (1), 2634.

Tuckman, Bruce Wayne. 1987.Conducting Educational Research. Ohio: Ohio State University Press.

Waites, Kate \& Robert R. Daniel. 2014. Relationship Between the Context of Elements and Illustration in Children's Book With The Ability of The Story's Contens. International Journal of Arts and Education, 4(1), 291-298.

Walker, Sue. 2012. "Describing The Design of Children Books: An Analytical Approach". Arts and Humanities Journal, 46 (3), 180-199.

.2015. Evidence-Based Programme for the Prevention and Reduction of Antisocial Behavior. .Journal of Character Education Partnership, 11(4), 77-87. 